\title{
RESPON SETEK TUMBUHAN RAMBUSA (Passiflora foetida L) TERHADAP KONSENTRASI DAN WAKTU PERENDAMAN ZAT PENGATUR TUMBUH (ZPT)
}

\section{RESPONSE OF RAMBUSA (Passiflora foetida L) CUTTINGS TO CONCENTRATION AND IMMERSION TIME OF GROWTH REGULTING SUBSTANCES (PGR)}

\author{
Hamidah $^{1}$, Jedebius Jenau ${ }^{2}$ \\ 1. Tenaga Pendidik Program Studi Agroteknologi, Fakultas Pertanian, Universitas Widya Gama Mahakam Jl KH. \\ Wahid Hasyim, Sempaja, Samarinda, Kalimantan Timur, Indonesia \\ 2. Mahasiswa Program Studi Agroteknologi, Fakultas Pertanian, Universitas Widya Gama Mahakam Jl KH. Wahid \\ Hasyim, Sempaja, Samarinda, Kalimantan Timur, Indonesia \\ Email: hamidah@uwgm.ac.id
}

Article Submitted: 09-11-2021

Article Accepted: 27-12-2021

\section{ABSTRACT}

Passiflora foetida L, better known as rambusa, grows in plantation areas, meadows, roadsides and vacant land. Rambusa is a plant that has not been widely used by the community. Rambusa plant (Passiflora foetida L) has various benefit, including s a medicine to treat bones, anemia, cancer, blood pressure, gums and teeth, kidney disorders, and stress. The part used in the rambusa plant is the fruit. The rambusa fruit contains calcium, iron, antioxidants, minerals and also vitamin C. Growth regulators (ZPT) are natural or synthetic organic compounds that promote, inhibit or modity qualitatively the growth and development of plants. Growth regulatrs play an important role in controlling biological processes in plat tissues. The aim of the study was to determine the effect of the concentration and duration of immersion in the appropriate ZPT for rambusa plants. The research was carried out on Jalan Pramuka, Gunung Kelua Village, Samarinda Ulu District, East Kalimantan for 3 (three) months starting from September 1 to Desember 1, 2021. The study was arranged in a Completely Randomized Design (RAK) with 2 factors 3 replications, namely: The first factor is the Concentration of ZPT Root Most (R) which consists of 3 (three) levels, namely : RO: Without PGR; R1 : 2 ml L ${ }^{-1}$. ; R2 ; 4 $\mathrm{ml} \mathrm{L-1}$. The second factor is the length of immersion $(P)$ which consists of 3 (three) levels, namely: P0; No Immersion; P1: Immersion 90 minutes; P2: Immersion 180 minutes. Research parameters, among other; Calculating the Percentage of Live Seeds; Plant length and number of shoots will be counted at 4, 8 and 12 weeks after planting. The results showed that the concentration treatment of Root Most $R 12 \mathrm{ml} \mathrm{L}^{-1}$ had a significant effect on the parameters of plant length 12 weeks after planting, which was $106.03 \mathrm{~cm}$. Treatment duration of immersion P1: immersion 90 minutes gave a significant effect on the parameters of plant length 12 weeks after planting, which was $102.11 \mathrm{~cm}$

Keywords: Rambusa, Root Most, Growth Regulator

\section{PENDAHULUAN}

Tumbuhan rambusa (Passiflora foetida L.) memiliki berbagai macam manfaat antara lain sebagai obat untuk mengobati tulang, anemia, kanker, tekanan darah, gusi dan gigi, gangguan ginjal, dan stress. Bagian yang dimanfaatkan pada tumbuhan rambusa yaitu buahnya. Buah rambusa memiliki kandungan kalsium, zat besi, antioksidan, mineral dan juga vitamin C (Dewi dan Afsari, 2017).

Memperhatikan besarnya manfaat tumbuhan rambusa, namun tumbuhan ini belum dibudidayan di masyarakat, maka perlu adanya penelitian pembudidayaan tumbuhan rambusa agar spesies tumbuhan ini tidak punah. Perbanyakan tumbuhan rambusa dilakukan dengan cara generative dan vegetative. Untuk vegetative bisa dilakukan dengan cara setek menggunakan ZPT Zat pengatur tumbuh (ZPT) adalah senyawa organik alami atau sintetis yang mempromosikan, menghambat atau memodifikasi pertumbuhan secara kualitatif dan perkembangan tanaman (Siti dkk, 2016).
Rombusa merupakan tumbuhan yang belum banyak dimanfaatkan oleh masyarakat (Rofiqoh, 2017).

Zat pengatur tumbuh berperan penting dalam mengontrol proses biologi dalam jaringan tanaman. Perannya antara lain mengatur kecepatan pertumbuhan dari masing-masing jaringan dan mengintegrasikan bagian-bagian tersebut untuk menghasilkan bentuk yang kita kenal sebagai tanaman (Siti dkk, 2016).

Pemanfaatan zat pengatur tumbuh untuk meningkatkan produksi tanaman merupakan salah satu teknologi yang dapat diaplikasikan. Zat pengatur tumbuh alami umumnya langsung tersedia di alam dan berasal dari bahan organik, contohnya air kelapa, urin sapi, dan ekstraksi dari bagian tanaman maupun mikroorganisme. Zat pengatur tumbuh sintetis didapat melalui proses produksi oleh manusia dan sudah dapat dipastikan rumus kimianya (Yunita, 2011).

Root Most merupakan salah satu Zat pengatur tumbuh yang dapat digunakan yang termasuk dalam pupuk organik cair dan ZPT (Basmal, 2009). 
Anjuran pada produk ZPT root most menerangkan bahwa untuk perendaman setek tanaman dibutuhkan $2 \mathrm{ml}$ root most yang diencerkan dalam 1 liter air, namun belum diketahui lama perendaman bahan stek dalam root most yang dapat meningkatkan pertumbuhan dan perkembangan stek tanaman yang optimum (Wilhelmus dan Kristno, 2019).S

Tujuan Penelitian Untuk mengetahui pengaruh konsentrasi dan lama perendaman ZPT yang tepat bagi tumbuhan rambusa.

\section{BAHAN DAN METODE}

Penelitian dilaksanakan di Jalan Pramuka Kelurahan Gunung Kelua Kecamatan Samarinda Ulu Kalimantan Timur selama 3 (tiga) bulan, terhitung dari 1 September sampai dengan 1 Desember 2021.

Alat yang digunakan adalah potray, polybag, cutter, meteran kain, penggaris, timbangan analitik, ember, alat tulis, gembor dan kamera.

Bahan yang akan digunakan dalam penelitian ini adalah setek tumbuhan rambusa, tanah lapisan atas, sekam padi dan kotoran hewan kandang sapi, atonik Rancangan Penelitian ini disusun dalam Rancangan Acak Lengkap (RAK) dengan 2 faktor dan 3 ulangan. Faktor pertama yaitu Konsentrasi ZPT Root Most (R) yang terdiri dari 3 (tiga) taraf, yaitu: R0 : Tanpa ZPT R1 : $2 \mathrm{ml} \mathrm{L}^{-1} \mathrm{R} 2: 4 \mathrm{ml} \mathrm{L}^{-1}$ Faktor kedua yaitu lama perendaman (P) yang terdiri dari 3 (tiga) taraf, yaitu: P0 : Tanpa Perendaman P1 : Perendaman 90 menit P2 : Perendaman 180 menit

Pelaksanaan Penelitian terdiri dari :

a. Persiapan Tempat Penelitian yang dibersihkan terlebih dahulu dari gulma.

b. Persiapan Media Tanam adalah tanah lapisan atas, sekam padi, dan kotoran hewan kandang sapi dengan perbandingan 1:1:1, diamkan selama 1 minggu.

c. Persiapan setek tumbuhan rambusa yang digunakan sesuai perlakuan yaitu setek diambil dari cabang yang belum pernah berbunga atau berbuah dengan panjang setek $20 \mathrm{~cm}$ atau 3 ruas.

\section{d. Perendaman}

Bahan stek yang telah disiapkan, direndam dalam larutan sesuai perlakuan. Setek di rendam pada bagian pangkal, perendaman setek dilakukan pada wadah yang berbeda sesuai dengan perlakuan yang diberikan.

e.Penanaman setek tumbuhan rambusa dalam polybag yang diletakkan pada tempat penelitian dengan jarak $15 \mathrm{~cm}$ antar polybag.

Pemeliharaan terdiri dari

a. Penyiraman dilakukan dengan menggunakan gembor, atau dengan memperhatikan kondisi di lapangan. b. Penyiangan Gulma dilakukan dengan memperhatikan kondisi di lapangan, penyiangan dilakukan secara manual pada gulma yang tumbuh di dalam polybag maupun di sekitar polybag.

Parameter penelitian

a. Menghitung Prosentase Setek Hidup yaitu Kemampuan hidup/prosentase hidup setek setelah pembibitan dalam satuan (\%) dengan menggunakan rumus sebagai berikut: Prosentase hidup tumbuhan $=$ jumlah tumbuhan hidup $\mathrm{x} \quad 100 \%$ jumlah tumbuhan ditanam

b. Panjang Tumbuhan rambusa diukur dengan menggunakan meteran kain dilakukan pada minggu ke 4,8 dan 12 setelah tanam

c. Jumlah Tunas dihitung mulai tumbuhnya sampai terakhir pengamatan, Jumlah Tunas dihitung pada minggu 12 setelah tanam.

Analisis data penelitian respon setek tumbuhan rambusa dilakukan dengan sidik ragam dan uji Beda Nyata Terkecil (BNT) taraf 5\%.

\section{HASIL DAN PEMBAHASAN}

\section{Prosentase Hidup Setek}

Hasil sidik ragam menunjukkan perlakuan Konsentrasi ZPT Root Most dan Lama Perendaman untuk parameter prosentase hidup setek tumbuhan rambusa tidak berberpengaruh nyata. Hasil pengamatan rata-rata prosentase Hidup setek tumbuhan rambusa disajikan pada tabel 1 .

Tabel 1. Rata-rata Prosentase Setek Hidup Tumbuhan Rambusa (\%).

\begin{tabular}{|c|c|c|c|c|}
\hline \multirow{2}{*}{$\begin{array}{l}\text { Root } \\
\text { Most }\end{array}$} & \multicolumn{2}{|c|}{$\begin{array}{c}\text { Lama } \\
\text { Perendaman }\end{array}$} & & \multirow[t]{2}{*}{ Rata - Rata \% } \\
\hline & P0 & P1 & P2 & \\
\hline R0 & 94,00 & 94,00 & 88,88 & 92,29 \\
\hline R1 & 100,00 & 100,00 & 100,00 & 100,00 \\
\hline $\mathrm{R} 2$ & 100,00 & 100,00 & 100,00 & 100,00 \\
\hline $\begin{array}{l}\text { Rata- } \\
\text { rata }\end{array}$ & 98,00 & 98,00 & 96,23 & \\
\hline
\end{tabular}

Keterangan *) Angka rata-rata yang diikuti huruf yang sama menunjukan tidak berbeda nyata pada uji BNT $5 \%$.

Persentase hidup setek tumbuhan rambusa tidak berpengaruh nyata diduga karena hormon yang berada dalam bentuk cair pada saat digunakan akan masuk dengan cepat ke dalam sel tumbuhan melalui proses difusi. Jika hormon yang masuk ke dalam sel tumbuhan tersebut terakumulasi, akan menghambat bagi tanaman itu sendiri dalam pertumbuhannya. Sesuai pendapat Irianto (2002) yang menyatakan bahwa akibat terakumulasinya hormon tertentu dalam jumlah besar di dalam sel tanaman akan menghambat kinerja dari hormn lainnya sehingga tumbuhan mengalami kesulitan untuk tumbuh. 
Hasil sidik ragam menunjukkan perlakuan Konsentrasi ZPT Root Most dan Lama Perendaman untuk parameter panjang tanaman umur 4 minggu setelah tanam berpengaruh nyata. Hasil pengamatan rata-rata panjang tumbuhan disajikan pada tabel 2 .

Tabel 2. Rata-rata Panjang Tumbuhan Rambusa Umur 4 minggu setelah tanam.

\begin{tabular}{ccccc}
\hline \multirow{2}{*}{ Root Most } & \multicolumn{2}{c}{ Lama } \\
& Perendaman & \multicolumn{3}{c}{ Rata - Rata (cm) } \\
\cline { 2 - 4 } & P0 & P1 & P2 & \\
\hline R0 & 20,67 & 25,89 & 22,44 & $\mathbf{2 3 , 0 0}^{\mathbf{c}}$ \\
R1 & 31,44 & 38,89 & 34,11 & $\mathbf{3 4 , 8 1}^{\text {a }}$ \\
R2 & 25,22 & 31,44 & 25,22 & $\mathbf{2 7 , 2 9}^{\text {b }}$ \\
\hline
\end{tabular}

Rata-rata $\quad 25,77^{\mathrm{c}} \quad 32,07^{\mathrm{a}} \quad 27,25^{\mathrm{b}}$

Keterangan *) Angka rata-rata yang diikuti huruf yang sama menunjukan tidak berbeda nyata pada uji BNT $5 \%$.

Hasil uji BNT 5\% pada Konsentrasi ZPT Root Most menunjukkan bahwa perlakuan R1; 2 ml $\mathrm{L}^{-1}$ untuk parameter panjang tanaman umur 4 minggu setelah tanam berbeda nyata dengan R0 dan R2. Rata-rata panjang tanaman tertinggi pada perlakuan R1 yaitu $34,81 \mathrm{~cm}$. Sedangkan rata-rata panjang tanaman terendah pada umur 4 minggu setelah tanam pada perlakuan R0 yaitu $23,00 \mathrm{~cm}$

Hasil uji BNT 5\% pada Lama Perendaman ZPT Root Most menunjukkan bahwa perlakuan P1; perendaman 90 menit untuk parameter panjang tanaman umur 4 mimggu setelah tanam berbeda nyata dengan P0 dan P2. Rata-rata panjang tanaman tertinggi pada perlakuan P1 yaitu 32,07 $\mathrm{cm}$. Sedangkan rata-rata panjang tanaman terendah pada umur 4 minggu setelah tanam pada perlakuan P0 yaitu $25.77 \mathrm{~cm}$

Hasil sidik ragam menunjukkan perlakuan Konsentrasi ZPT Root Most dan Lama Perendaman untuk parameter panjang tumbuhan umur 8 minggu setelah tanam berpengaruh nyata. Hasil pengamatan rata-rata panjang tumbuhan disajikan pada tabeL 3 .

Tabel 3. Rata-rata Panjang Tumbuhan Rambusa Umur 8 Minggu Setelah Tanam

\begin{tabular}{lcc}
\hline Root Most & Lama & Perendaman
\end{tabular}

\begin{tabular}{ccccc} 
& P0 & P1 & P2 & \\
\hline R0 & 38,33 & 58,11 & 42,44 & $\mathbf{4 6 , 2 2}^{\mathbf{c}}$ \\
R1 & 70,78 & 98,44 & 85,22 & $\mathbf{8 4 , 8 1}^{\text {a }}$ \\
R2 & 48,67 & 78,00 & 61,67 & $\mathbf{6 2 , 7 8}^{\text {b }}$ \\
\hline
\end{tabular}

\begin{tabular}{lll}
\hline Rata-rata & $\mathbf{5 2 , 5 9}^{\mathbf{c}} \quad \mathbf{7 8 , 1 \mathbf { 1 } ^ { \mathbf { a } }} \mathbf{6 3 . 1 1}^{\mathbf{b}}$ \\
\hline Keterangan & *) & Angka rata-rata yang diikuti huruf \\
& yang sama menunjukan tidak \\
& berbeda nyata pada uji BNT $5 \%$.
\end{tabular}

Hasil uji BNT 5\% pada Konsentrasi ZPT Root Most menunjukkan bahwa perlakuan R1; 2 ml $\mathrm{L}^{-1}$ untuk parameter panjang tanaman umur 8 minggu setelah tanam berbeda nyata dengan $\mathrm{R} 0$ dan R2. Rata-rata panjang tanaman tertinggi pada perlakuan R1 yaitu $84,81 \mathrm{~cm}$. Sedangkan rata-rata panjang tanaman terendah pada umur 8 minggu setelah tanam pada perlakuan R0 yaitu 46,22 cm

Hasil uji BNT 5\% pada Lama Perendaman ZPT Root Most menunjukkan bahwa perlakuan P1; perendaman 90 menit untuk parameter panjang tanaman umur 8 mimggu setelah tanam berbeda nyata dengan P0 dan P2. Rata-rata panjang tanaman tertinggi pada perlakuan P1 yaitu 78,18 $\mathrm{cm}$. Sedangkan rata-rata panjang tanaman terendah pada umur 8 minggu setelah tanam pada perlakuan P0 yaitu 52,89 cm

Hasil sidik ragam menunjukkan perlakuan Konsentrasi ZPT Root Most dan Lama Perendaman untuk parameter panjang tanaman umur 12 minggu setelah tanam berpengaruh nyata. Hasil pengamatan rata-rata panjang tumbuhan disajikan pada tabel 4.

Tabel 4. Rata-rata Panjang Tumbuhan Rambusa Umur 12 Minggu Setelah Tanam

\begin{tabular}{|c|c|c|c|c|}
\hline \multirow{2}{*}{$\begin{array}{l}\text { Root } \\
\text { Most }\end{array}$} & \multicolumn{2}{|c|}{$\begin{array}{c}\text { Lama } \\
\text { Perendaman }\end{array}$} & \multicolumn{2}{|r|}{ Rata - Rata $(\mathrm{cm})$} \\
\hline & P0 & P1 & P2 & \\
\hline R0 & 63,33 & 77,22 & 77,44 & $72,66^{c}$ \\
\hline R1 & 97,67 & 120,00 & 100,44 & $106,03^{\mathrm{a}}$ \\
\hline $\mathrm{R} 2$ & 79,67 & 109,11 & 99,56 & $96,11^{a b}$ \\
\hline Rata-rata & 80,22 & 102,11 & 92,48 & \\
\hline
\end{tabular}

Keterangan *) Angka rata-rata yang diikuti huruf yang sama menunjukan tidak berbeda nyata pada uji BNT $5 \%$.

Hasil uji BNT 5\% pada Konsentrasi ZPT Root Most menunjukkan bahwa perlakuan R1; $2 \mathrm{ml}$ $\mathrm{L}^{-1}$ untuk parameter panjang tanaman umur 12 minggu setelah tanam berbeda nyata dengan $\mathrm{R} 0$ dan R2. Rata-rata panjang tanaman tertinggi pada perlakuan R1 yaitu 106,03 cm. Sedangkan rata-rata panjang tanaman terendah pada umur 12 minggu setelah tanam pada perlakuan R0 yaitu 72,66 cm

Hasil uji BNT 5\% pada Lama Perendaman ZPT Root Most menunjukkan bahwa perlakuan P1; perendaman 90 menit untuk parameter panjang tanaman umur 12 mimggu setelah tanam berbeda nyata dengan $\mathrm{P} 0$ dan $\mathrm{P} 2$. Rata-rata panjang tanaman tertinggi pada perlakuan P1 yaitu 102,11 $\mathrm{cm}$. Sedangkan rata-rata panjang tanaman terendah pada umur 12 minggu setelah tanam pada perlakuan P0 yaitu $80,22 \mathrm{~cm}$

\section{Jumlah Cabang (buah)}

Hasil sidik ragam menunjukkan perlakuan Konsentrasi ZPT Root Most dan Lama Perendaman untuk parameter jumlah cabang tumbuhan umur 12 
minggu setelah tanam tidak berpengaruh nyata. Hasil pengamatan rata-rata jumlah cabang tumbuhan disajikan pada tabel 5 .

Tabel 5. Rata-rata Jumlah Cabang Tumbuhan Rambusa Umur 12 Minggu Setelah Perlakuan

\begin{tabular}{ccccc}
\hline \multirow{2}{*}{$\begin{array}{c}\text { Root } \\
\text { Most }\end{array}$} & \multicolumn{2}{c}{$\begin{array}{c}\text { Lama } \\
\text { Perendaman }\end{array}$} & \multicolumn{2}{c}{ Rata - Rata (cm) } \\
\cline { 2 - 4 } & P0 & P1 & P2 & \\
\hline R0 & 0,00 & 0,33 & 0,33 & $\mathbf{0 , 2 2}$ \\
R1 & 1,00 & 1,33 & 1,00 & $\mathbf{1 , 1 1}$ \\
R2 & 0,66 & 1,33 & 0,66 & $\mathbf{0 , 8 8}$ \\
\hline Rata- & & & & \\
rata & $\mathbf{0 , 5 5}$ & $\mathbf{0 , 9 9}$ & $\mathbf{0 , 6 6}$ & \\
\hline Keterangannnn
\end{tabular}

Keterangan *) Angka rata-rata yang diikuti huruf yang sama menunjukan tidak berbeda nyata pada uji BNT $5 \%$.

Hasil uji BNT 5\% pada perlakuan konsentrasi ZPT Root Most dan lama perendaman menunjukkan bahwa perlakuan P1; perendaman 90 menit untuk parameter panjang tanaman umur 12 mimggu setelah tanam berbeda nyata dengan P0 dan P2. Rata-rata panjang tanaman tertinggi pada perlakuan P1 yaitu $102,11 \mathrm{~cm}$. Sedangkan rata-rata panjang tanaman terendah pada umur 12 minggu setelah tanam pada perlakuan P0 yaitu $80,22 \mathrm{~cm}$

Pemberian konsentrasi zat pengatur tumbuh dan lama perendaman pada tumbuhan rambusa untuk mempercepat pertumbuhan akar. Hasil uji BNT $5 \%$ pada tumbuhan rambusa umur 4, 8 dan 12 minggu setelah tanam berbeda nyata. Hal ini diduga pada tumbuhan rambusa umur 4, 8 dan 12 minggu setelah tanam telah memili perakaran yang sempurna, sehingga dapat menyerap baik air maupun hara lainnya dengan baik, sesuai pendapat Swestiani dan Aditya (2008) yang mengatakan bahwa akar mempunyai fungsi menghisap air serta garam-garam mineral dan oksigen dari dalam tanah, berfungsi sebagai jangkar bagi tumbuhan, sebagai penghubung dalam mengalirkan air, garam-garam mineral dan zat makanan lainnya ke batang dan daun yang berada diatasnya.

Pemberian zat pengatur tumbuh dengan konsentrasi yang tepat akan memberikan pengaruh terhadap pertumbuhan dan perkembangan tanaman. Pada kadar rendah hormon atau zat pengatur tumbuh akan mendorong pertumbuhan, sedangkan pada kadar yang lebih tinggi akan menghambat pertumbuhan, meracuni bahkan mematikan tanaman (Supriyanto dan Kaka, 2011)

\section{KESIMPULAN}

Konsentrasi Penggunaan Zat Pengatur Tumbuh (ZPT) Root Most berpengaruh nyata pada parameter panjang tumbuhan yaitu perlakuan R1 : 2 $\mathrm{ml} \mathrm{L}^{-1}$ dengan umur 12 minggu setelah tanam yaitu $106,03 \mathrm{~cm}$.
Lama Perendaman Zat Pengatur Tumbuh (ZPT) Root Most yang berpengaruh nyata pada prameterpanjang tumbuhan adalah Perlakuan P1 : perendaman 90 menit umur 12 minggu setelah tanam yaitu $102,11 \mathrm{~cm}$.

\section{UCAPAN TERIMA KASIH}

Terima kasih dan apresiasi yang sebesarbesarnya kepada :

Ketua Pengurus Yayasan Pembina Pendidikan Mahakam, Rektor Universitas Widya Gama Mahakam Samarinda, Kepala Lembaga Penelitian Dan Pengabdian Masyarakat UWGM Samarinda, Dekan Fakultas Pertanian UWGM Samarinda serta semua pihak yang telah membantu yang tidak dapat disebutkan satu persatu, atas bantuan dana internal Universitas Widya Gama Mahakam Samarinda pada skim hibah penelitian Tahun Akademik Ganjil 2021/2022.

\section{DAFTAR PUSTAKA}

Basmal, J. 2009. Prospek Pemanfaatan Rumput Laut Sebagai Bahan Pupuk Organic.J. Squad, $4(1): 1-8$.

Dewi, S.T.R., dan Afsari, Y. 2017. Uji Aktivitas Ekstrak Buah Rambusa (Passiflora foetida L.) terhadap Kerusakan Gigi Penyebab Bakteri Streptococcus mutans. Media Farmasi. 13(2): 92.

Febry Elvy Pakpahan, Nur Azizah dan Sudiarso, 2018. Pengaruh Berbagai Konsentrasi ZPT Atonik Pada Pertumbuhan Berbagai Asal Batang Setek Sirih Merah (Piper crocatum Ruiz and Pav.

Herbarium Medanense. 2019. Hasil Identifikasi Tumbuhan Rambusa. Herbarium Medanense (MEDA). Universitas Sumatera Utara.

Hidayanto, M.S, Nurjanah dan F. Yosita. 2010. Pengaruh Panjang Setek Akar dan Konsentrasi Natriumnitrofenol Terhadap Pertumbuhan Setek Akar Sukun (Artocarpus commus F.) Pengkajian dan Pengembangan Teknologi Pertanian. 6 (2); 154- 160

Irianto, 2002., Pengaruh Hormon IBA (Indole Butyric Acid) Terhadap Persen Jadi Setek Pucuk Meranti Putih (Shorea montigena). UniversitasPattimuraAmbon.http://www.free webs.com/irwantoshut/short.

Noorcahyati. 2002. Tumbuhan Berkhasiat Obat Etnis Asli Kalimantan. Kalimantan Timur: Balai Penelitian Teknologi Konservasi Sumber Daya Alam. h 56 
Rofiqoh, R. K. 2017. Efek Antioksidan Ekstrak Daun Rambusa (Passiflora foetida) dan Taurin terhadap Respon Histopatologi Hati Mencit (Mus musculus) yang diinduksi Paraquat. Skripsi. Fakultas Matematika dan Ilmu Pengetahuan Alam. Universitas Lampung. Lampung. h 20-22.

Siti Aisyah, M. Mardhiansyah, Tuti Arlita, 2016. Aplikasi Berbagai Jenis Zat Pengatur Tumbuh (ZPT) Terhadap Pertumbuhan Semai Gaharu (Aquilaria malaccensis Lamk) Fakultas Pertanian Universitas Riau Jom Faperta Vol.3 No.1 Februari 2016 Steenis, C. G. G. J. Van. 2003. Flora. Cet. 9. PT Pradnya Paramitha, Jakarta
Supriyanto dan Kaka. E. P. 2011. Pengaruh Zat Pengatur Tumbuh Rootone-F Terhadap Pertumbuhan Stek Duabanga Mollucana Blume. Jurnal Silvikultur Tropika Vol.03 No.01 Agustus 2011. Hal 59-65.

Swestiani. D. dan Aditya. H. 2008. Perbandingan Pemberian Empat Jenis Zat Pengatur Tumbuh Pada Stek Cabang Sungkai (Peronema canescens Jack). Balai Penelitian Kehutanan Ciamis. Jawa Barat.

Yunita.R. 2011. Pengaruh Pemberian Urine Sapi, Air Kelapa, dan Rootone F Terhadap Pertumbuhan Setek Tanaman Markisa (Passifloraedulis var.flavicarpa). Skripsi Universitas Andalas. Sumatera Barat. 